\title{
Ketahanan padi (Oryza sativa L.) varietas IPB 3S terhadap wereng batang cokelat (Nilaparvata lugens (Stål)) (Hemiptera: Delphacidae)
}

\author{
IPB 3S rice (Oryza sativa L) variety resistancy against brown \\ planthopper (Nilaparvata lugens (Stål)) (Hemiptera: Delphacidae)
}

\author{
Andi Nurdaaniyah*, Dadang, I Wayan Winasa \\ Departemen Proteksi Tanaman, Fakultas Pertanian, Institut Pertanian Bogor \\ Jalan Kamper, Kampus IPB Dramaga, Bogor 16680
}

(diterima Desember 2018, disetujui Juli 2020)

\begin{abstract}
ABSTRAK
Wereng batang cokelat (WBC) (Nilaparvata lugens (Stål)) merupakan hama utama yang menyebabkan kerusakan dalam waktu singkat pada tanaman padi. Penanaman varietas padi tahan dapat digunakan untuk menekan serangan WBC. Penelitian bertujuan untuk memelajari ketahanan varietas IPB $3 \mathrm{~S}$ melalui pengujian keperidian, nisbah kelamin, aktivitas makan, dan peningkatan populasi menggunakan pembanding varietas Ciherang terhadap WBC (N. lugens). Pengujian keperidian menggunakan sepasang imago WBC diinfestasikan pada padi berumur 21 hari setelah tanam (HST). Telur yang diletakkan maupun tidak diletakkan pada pelepah padi dihitung. Perbandingan nisbah kelamin dilakukan menggunakan sepasang imago WBC yang diinfestasikan pada padi berumur 30 HST dan dibiarkan bertelur kemudian membandingkan jumlah imago jantan dan betina. Untuk aktivitas makan WBC, pengujian dilakukan menggunakan sepuluh nimfa instar empat yang diinfestasikan pada padi berumur 30 HST. Ekskresi WBC berupa embun madu yang tertampung pada kertas saring yang sebelumnya telah disemprot ninhidrin selanjutnya dianalisis secara kualitatif dengan spektrofotometer. Peningkatan populasi dilakukan dengan menginfestasikan lima pasang imago WBC pada tanaman padi berumur 35 HST. Pengamatan dilakukan pada fase nimfa dan imago yang dilakukan selama empat generasi. Setiap pengujian diulang 10 kali. Secara umum, varietas IPB $3 \mathrm{~S}$ memiliki ketahanan terhadap WBC jika dibandingkan dengan varietas Ciherang. Hal ini terutama terlihat dari kemampuan makan WBC yang lebih tinggi pada varietas Ciherang dibandingkan pada IPB 3S. Keperidian dan peningkatan populasi WBC pada kedua varietas adalah sama.
\end{abstract}

Kata kunci: Ciherang, kemampuan makan, keperidian, nisbah kelamin

\begin{abstract}
Brown planthopper (Nilaparvata lugens (Stål)) is one of the major rice insect pests that is known to cause high loss of rice production. One of the strategies to control this pest is by using resistant rice varieties. The aim of this research was to study the resistance of IPB $3 \mathrm{~S}$ variety to BPH by measuring BPH fecundity, sex ratio, feeding activity as well as population increase compared to Ciherang variety against brown planthopper ( $N$. lugens). Fecundity test used a pair of BPH adult infested on 21 days after planting (DAP) of rice plants. Eggs laid in rice stalks and the rest of eggs in the ovary were counted. In order to know the change of sex ratio, a pair of BPH adults was infested on 30 DAP rice plants and allowed to lay eggs. The calculation of sex ratio was conducted at adult stage of BPH by segregation between male and female adults. Feeding activity of BPH was evaluated using ninhydrin and analyzed qualitatively using spectrophotometer. Ten fourth instar nymphs of
\end{abstract}

\footnotetext{
*Penulis korespondensi: Andi Nurdaaniyah. Program Studi Entomologi, Departemen Proteksi Tanaman, Fakultas Pertanian, Institut Pertanian Bogor, Jalan Kamper, Kampus IPB Dramaga, Bogor 16680, Tel: 0251-8629364, Faks: 0251-8629362, Email: andi_nia93@yahoo.com
} 
BPH was infested on 30 DAP old of rice seedlings. Honeydew secreted by BPH was collected to filter paper sprayed with ninhydrin. Population increased test was conducted by infesting five pairs of BPH adults on 35 DAP old rice plants. Observations was conducted on nymph and adult stages. Each test was replicated 10 times. In general, IPB $3 \mathrm{~S}$ is slightly resistant to BPH, compared to Ciherang variety. The feeding activity of BPH is higher in Ciherang compared to IPB3S. However, the fecundity and population increased of BPH in Ciherang is similar to IPB3S.

Key words: Ciherang, fecundity, feeding activity, sex ratio

\section{PENDAHULUAN}

Padi (Oryza sativa L.) di Indonesia merupakan salah satu sumber makanan pokok dan komoditas paling penting. Peningkatan jumlah penduduk mengakibatkan persediaan beras juga harus meningkat sehingga perlu adanya peningkatan produksi padi. Menurut BPS (2016) produksi padi nasional mengalami peningkatan sejak tahun 2010 hingga 2016, yaitu dari 66 juta ton menjadi 79 juta ton. Strategi untuk mencapai upaya peningkatan produksi padi di antaranya dengan peningkatan produktivitas, memperluas areal tanam, dan mengoptimalkan penggunaan lahan. Akan tetapi, adanya serangan organisme pengganggu tanaman (OPT) menjadi kendala dalam upaya peningkatan produksi padi.

Hama wereng batang cokelat (WBC) (Nilaparvata lugens (Stål)) (Hemiptera: Delphacidae) merupakan hama utama yang menyebabkan kerusakan dalam waktu singkat pada tanaman padi (Sari et al. 2019). Kerusakan tanaman padi akibat WBC menyebabkan pertumbuhan tanaman terhambat dan pada populasi yang tinggi menyebabkan tanaman padi mati atau dapat mengakibatkan puso (hopperburn), hal tersebut terjadi karena WBC menghisap cairan pada sel tanaman padi. Selain menyebabkan kerusakan langsung, peran WBC juga sebagai vektor virus penyebab penyakit berupa kerdil hampa dan kerdil rumput dengan serangan tinggi. Serangan akibat WBC dapat terjadi pada semua fase pertumbuhan tanaman padi dari pembibitan hingga menjelang panen (Harini et al. 2013).

Upaya yang dapat dilakukan untuk menekan serangan OPT tersebut dengan penanaman varietas padi tahan yang tingkat keefektifannya cukup dan aman. Varietas IPB 3S adalah varietas padi tipe baru (PTB) yang dirilis oleh Institut Pertanian Bogor tahun 2012. Keunggulan padi varietas IPB $3 \mathrm{~S}$ adalah cenderung tahan terhadap penyakit tungro, blas, dan hawar daun bakteri. Akan tetapi, belum ada laporan yang berkaitan dengan ketahanan padi varietas IPB 3S terhadap WBC. Tujuan penelitian ini untuk mempelajari ketahanan padi varietas IPB 3S terhadap WBC melalui pengujian keperidian, nisbah kelamin, aktivitas makan, dan peningkatan populasi dengan varietas Ciherang sebagai pembanding.

\section{BAHAN DAN METODE}

Penelitian dilakukan di Laboratorium Fisiologi dan Toksikologi Serangga, Departemen Proteksi Tanaman, Fakultas Pertanian; dan Laboratorium Spektroskopi, Departemen Fisika, Fakultas Matematika dan Ilmu Pengetahuan Alam, Institut Pertanian Bogor yang berlangsung dari bulan Oktober 2017 sampai Juni 2018. Rancangan percobaan yang digunakan dalam penelitian ini adalah rancangan acak lengkap (RAL) dengan jumlah ulangan 10 kali.

\section{Penanaman padi}

Masing-masing benih padi varietas IPB 3S dan Ciherang ditaburkan pada permukaan media tanam pada baki penyemaian (diameter $20 \mathrm{~cm}$ dan tinggi $5 \mathrm{~cm}$ ) yang mengandung tanah dan pupuk kandang $(2: 1 ; \mathrm{w} / \mathrm{w})$ dalam kondisi macak-macak. Setelah berumur tujuh hari setelah semai, masingmasing sebanyak 4 bibit padi dipindahtanamkan ke pot-pot plastik (diameter $10 \mathrm{~cm}$ dan tinggi $12 \mathrm{~cm}$ ) yang sebelumnya telah diisi dengan media tanam yang komposisinya sama dengan media tanam untuk persemaian. Bibit padi yang telah berumur 14 hari setelah tanam (HST) dipindahtanamkan pada pot plastik (diameter $25 \mathrm{~cm}$, tinggi $30 \mathrm{~cm}$ ), kemudian dipelihara hingga berumur 35 HST yang selanjutnya digunakan untuk perbanyakan WBC. 


\section{Perbanyakan wereng batang cokelat}

Sepuluh pasang imago WBC yang berasal dari Kebun Percobaan, Balai Besar Penelitian Tanaman Padi di Muara Bogor diambil dari kurungan lalu dipindahkan ke tanaman padi berumur 35 HST dengan menggunakan aspirator. Padi yang telah diinfestasi WBC disungkup dengan kurungan plastik mika berbentuk silinder (diameter $23 \mathrm{~cm}$ dan tinggi $65 \mathrm{~cm}$, pada bagian atas diberi kain kasa). Setelah 13 hari infestasi, imago WBC dikeluarkan. Nimfa instar empat digunakan sebagai serangga uji untuk pengujian kemampuan makan WBC, sedangkan imago yang terbentuk digunakan untuk pengujian keperidian, nisbah kelamin, dan peningkatan populasi WBC.

\section{Pengujian keperidian}

Pengujian keperidian dilakukan dengan menggunakan sepasang imago WBC yang diinfestasikan pada tiga bibit padi berumur 21 HST yang ditanam pada pot-pot plastik (diameter $10 \mathrm{~cm}$ dan tinggi $12 \mathrm{~cm}$ ), kemudian pot-pot plastik disungkup dengan kurungan plastik mika berbentuk silinder (diameter $10 \mathrm{~cm}$ dan tinggi $30 \mathrm{~cm}$ pada bagian atasnya diberi kasin kasa). Pengujian diulang 10 kali untuk masing-masing varietas. Setiap dua hari sekali sebanyak enam kali, sepasang imago yang telah diinfestasi dipindahkan menggunakan aspirator pada tanaman baru, seperti diuraikan di atas. Penghitungan jumlah telur WBC dilakukan baik telur yang terdapat pada jaringan pelepah padi maupun sisa telur yang terdapat dalam ovari serangga melalui pembedahan abdomen WBC di bawah mikroskop. Kebugaran (fitness) berkaitan dengan reproduksi dinyatakan dengan potensi keperidian (Ellers \& Jervis 2003):

$$
\underset{\text { keperidian }}{\text { Potensi }}=\text { Keperidian riil }+\underset{\text { Jumlah telur }}{\text { dalam ovari }}
$$

Keperidian riil: jumlah telur yang diletakkan pada tanaman inang selama hidup imago.

\section{Pengujian nisbah kelamin}

Pengujian nisbah kelamin dilakukan dengan menginfestasikan sepasang imago WBC pada tanaman padi yang diuji (Ciherang dan IPB 3S) berumur 30 HST yang ditanam pada pot plastik (diameter $25 \mathrm{~cm}$ dan tinggi $30 \mathrm{~cm}$ ) yang telah diisi media tanam kemudian pot plastik tersebut disungkup dengan kurungan plastik mika berbentuk silinder (diameter $23 \mathrm{~cm}$ dan tinggi $65 \mathrm{~cm}$ dan bagian atasnya diberi kain kasa). Pengujian diulang 10 kali untuk setiap varietas. WBC dibiarkan makan, meletakkan telur hingga berkembang menjadi imago. Imago yang terbentuk diambil dan dihitung jumlah jantan dan betinanya. Nisbah kelamin selanjutnya dihitung menggunakan rumus:

$$
\text { Nisbah kelamin }=\frac{\text { Jumlah imago WBC jantan }}{\text { Jumlah imago WBC betina }}
$$

\section{Pengujian kemampuan makan}

Pengujian kemampuan makan melalui ekskresi embun madu dilakukan menggunakan bibit padi berumur 30 HST. Bibit padi ditanam sedikit agak miring pada gelas plastik (diameter $5,5 \mathrm{~cm}$ dan tinggi $4,5 \mathrm{~cm}$ ) yang sebelumnya telah diisi media tanam sampai penuh. Petri plastik (diameter $9 \mathrm{~cm}$ ) yang bagian tengahnya berlubang ditempatkan pada gelas plastik sehingga bibit padi berdiri di tengah lubang petri plastik. Kertas saring dipotong berbentuk lingkaran berdiameter $8,5 \mathrm{~cm}$ kemudian pada salah satu jari-jarinya digunting. Kertas saring disemprot dengan $0,5 \mathrm{ml}$ larutan ninhidrin $10 \mathrm{ppm}$ dalam aseton kemudian ditempatkan di atas petri dan bibit padi disematkan pada kertas saring tersebut. Sebanyak 10 individu nimfa instar empat WBC diinfestasikan pada bibit padi kemudian disungkup dengan gelas plastik (diameter $10 \mathrm{~cm}$ dan tinggi $12 \mathrm{~cm}$ ) selanjutnya dibiarkan makan selama 24 jam. Pengujian diulang 10 kali untuk masing-masing varietas. Setelah 24 jam, kertas saring dipotong delapan bagian kemudian direndam dalam $5 \mathrm{ml}$ aseton pada cawan petri (diameter $8,5 \mathrm{~cm}$ ) selama kurang lebih 5 jam. Setelah 5 jam, potongan kertas saring dikeluarkan dan hasil rendaman selanjutnya dipindahkan ke masing masing botol kaca dan ditambahkan aseton hingga volumenya mencapai $5 \mathrm{ml}$. Masing-masing sampel kemudian dilakukan analisis kualitatif meng-gunakan spektrofotometer (BEL engineering UV-M51) dengan panjang gelombang 300-369 nm, untuk mengetahui nilai absorbansinya.

\section{Pengujian peningkatan populasi}

Pengujian peningkatan populasi WBC dilakukan untuk mengetahui populasi yang terbentuk dari kedua varietas padi, melalui 
pengujian selama empat generasi WBC (dimulai dari generasi ke-0, generasi pertama, kedua, dan ketiga). Pengujian awal (generasi ke-0) dilakukan dengan menginfestasikan lima pasang imago jantan dan betina WBC yang baru terbentuk dari tanaman padi barumur 35 HST yang telah ditanam pada pot plastik (diameter $25 \mathrm{~cm}$ dan tinggi 30 $\mathrm{cm}$ ), selanjutnya pot-pot plastik disungkup dengan kurungan plastik mika berbentuk silinder (diameter $23 \mathrm{~cm}$ dan tinggi $65 \mathrm{~cm}$ pada bagian atasnya diberi kain kasa), kemudian dibiarkan selama 13 hari. Setelah 13 hari, semua imago yang masih hidup dikeluarkan lalu dimatikan. Tahap pengujian generasi pertama, kedua, dan ketiga sama dengan tahap pengujian generasi ke-0. Sebanyak lima pasang imago WBC yang terbentuk dari generasi ke-0 digunakan untuk pengujian generasi pertama, dan seterusnya untuk generasi kedua, dan ketiga. Setiap tanaman yang digunakan berumur 35 HST. Pengujian diulang sebanyak 10 kali untuk masingmasing varietas. Pengamatan dilakukan pada fase nimfa dan imago (28 hari setelah infestasi).

\section{Analisis data}

Pengujian keperidian, nisbah kelamin, dan peningkatan populasi WBC pada dua varietas padi dianalisis dengan uji $\mathrm{t}$ menggunakan perangkat lunak SAS (Priyatno 2013).

\section{HASIL}

\section{Keperidian}

Rata-rata jumlah telur yang diletakkan WBC pada varietas Ciherang dari dua hari pertama hingga hari ke-12 berturut-turut sebanyak 0; 9,2; 62,$7 ; 129,0 ; 98,1$; dan 55,5 telur/betina, sedangkan pada varietas IPB $3 \mathrm{~S}$ berutut-turut sebesar $0 ; 30,9$; 54,$0 ; 85,8 ; 127,6$; dan 45,7 telur/betina (Gambar 1).

Varietas Ciherang memiliki keperidian riil sebesar 354,50 telur/betina yang lebih tinggi dari keperidian riil varietas IPB 3S sebesar 344,00 telur/betina, namun tidak berbeda nyata $(\mathrm{t}=$ $0,32 ; \mathrm{P}=0,75)$. Jumlah telur dalam ovari pada varietas IPB $3 \mathrm{~S}$ sebesar 60,10 telur/betina yang menunjukkan lebih banyak dibandingkan dengan varietas Ciherang sebesar 57,10 telur/betina, namun tidak berbeda nyata $(\mathrm{t}=0,52 ; \mathrm{P}=0,61)$ Dengan demikian, potensi keperidian pada varietas Ciherang sebesar 411,60 telur/betina lebih tinggi dibandingkan dengan varietas IPB $3 \mathrm{~S}$ sebesar 404,10 telur/betina, namun tidak menunjukkan perbedaan nyata $(\mathrm{t}=0,26 ; \mathrm{P}=0,79)($ Tabel 1$)$.

\section{Nisbah kelamin}

Hasil uji $\mathrm{T}$ nisbah kelamin (jantan:betina) WBC antara varietas Ciherang dan varietas IPB 3S menunjukkan perbedaan nyata, yaitu berturutturut sebesar 1:2,66 dan 1:2,05 $(\mathrm{t}=10,92 ; \mathrm{P}=$ $0,00)$ (Tabel 1).

\section{Peningkatan populasi}

Peningkatan populasi WBC pada varietas Ciherang generasi ke-0 sebesar 1.348,4 tidak berbeda nyata dengan varietas IPB $3 \mathrm{~S}$ sebesar $1.330,4(\mathrm{t}=0,29 ; \mathrm{P}=0,77)$, varietas Ciherang pada generasi ke-1 sebesar 1.698,5 tidak berbeda nyata dengan varietas IPB $3 \mathrm{~S}$ sebesar 1.667,1 $(\mathrm{t}=1,12$; $\mathrm{P}=0,28)$, varietas Ciherang generasi ke-2 sebesar $1.717,5$ tidak berbeda nyata dengan varietas IPB

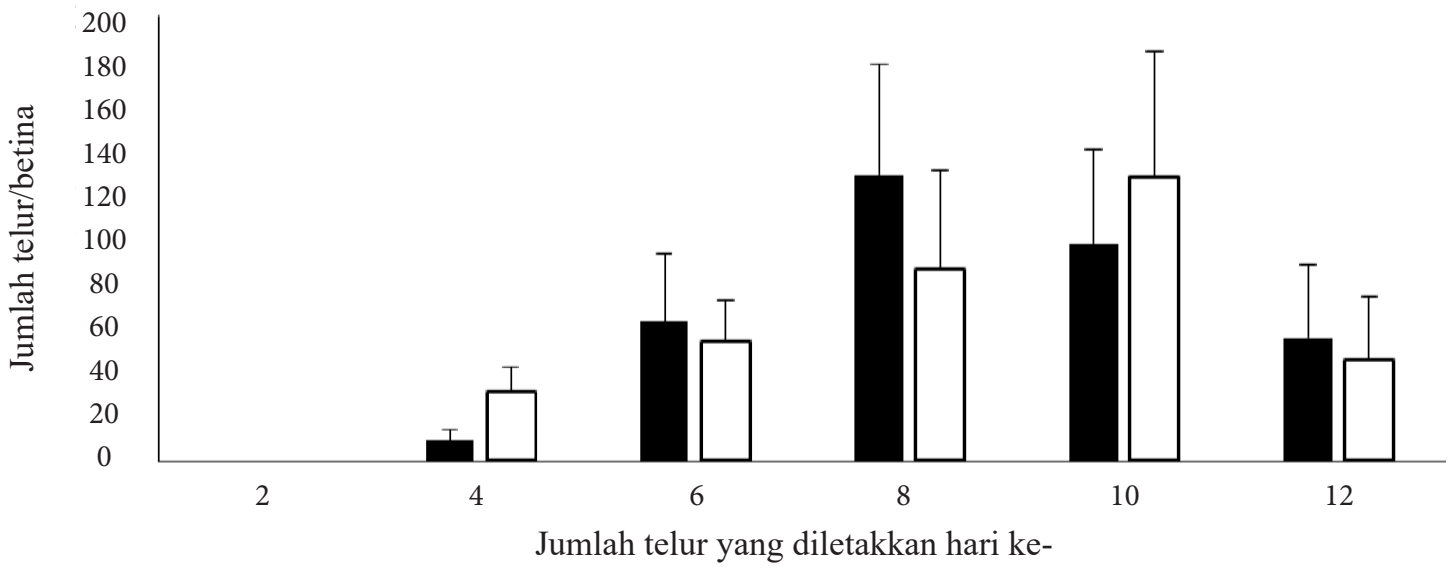

Gambar 1. Rata-rata jumlah telur yang diletakkan oleh wereng batang cokelat pada dua varietas padi. Ciherang; $\square$ : IPB 3 S. 
3S sebesar 1.609,3 $(\mathrm{t}=1,43 ; \mathrm{P}=0,18)$, dan pada generasi ke-3 varietas Ciherang sebesar 1.727,9 tidak berbeda nyata dengan varietas IPB $3 \mathrm{~S}$ sebesar 1.679,9 $(\mathrm{t}=1,28 ; \mathrm{P}=0,23)($ Tabel 2).

\section{Kemampuan makan}

Hasil pengujian embun madu berdasarkan analisis kualitatif pada panjang gelombang $332 \mathrm{~nm}$ menunjukkan bahwa nilai absorbansi varietas Ciherang lebih tinggi dibandingkan dengan varietas IPB 3S. Nilai absorbansi varietas Ciherang sebesar 1,89, sedangkan nilai absorbansi varietas IPB 3S sebesar 1,35 (Gambar 2).

\section{PEMBAHASAN}

Secara umum telur yang diletakkan WBC pada varietas Ciherang jumlahnya lebih banyak dibandingkan pada varietas IPB 3S. Hal ini tampak dari hasil keperidian riil.

Pada dua hari pertama, WBC belum meletakkan telur karena masih berada dalam periode/masa praoviposisi, yaitu selama 2-3 hari. Hari ke-4 WBC mulai meletakkan telur baik pada varietas Ciherang maupun pada varietas IPB 3S, namun jumlah telur yang diletakkan masih sedikit. Jumlah telur yang diletakkan WBC pada hari ke-6 hingga hari ke-10 merupakan puncak peneluran, namun pada hari ke-12 pada dua varietas mengalami penurunan jumlah telur. WBC pada perlakuan varietas rentan menunjukkan respons fitness yang tinggi dibandingkan pada varietas tahan. Nurbaeti et al. (2010) menyatakan bahwa WBC betina mampu meletakkan telur dalam jumlah ratusan (270-902 butir) dengan model peletakan telur secara berkelompok. Hal ini sejalan dengan hasil penelitian yang diperoleh bahwa potensi

Tabel 1. Rata-rata keperidian dan nisbah kelamin wereng batang cokelat pada dua varietas padi

\begin{tabular}{lcccc}
\hline Varietas & $\begin{array}{c}\text { Potensi keperidian riil } \\
\text { (telur/betina) }\end{array}$ & $\begin{array}{c}\text { Telur dalam ovari } \\
\text { (telur/betina) }\end{array}$ & $\begin{array}{c}\text { Potensi keperidian } \\
\text { (telur/betina) }\end{array}$ & $\begin{array}{c}\text { Nisbah kelamin } \\
\text { (jantan:betina) }\end{array}$ \\
\hline Ciherang & $354,50 \pm 71,60 \mathrm{a}$ & $57,10 \pm 11,22 \mathrm{a}$ & $411,60 \pm 72,99 \mathrm{a}$ & $1: 2,66 \mathrm{a}$ \\
IPB 3S & $344,00 \pm 133,58 \mathrm{a}$ & $60,10 \pm 11,69 \mathrm{a}$ & $404,10 \pm 133,10 \mathrm{a}$ & $1: 2,05 \mathrm{~b}$ \\
\hline
\end{tabular}

Angka-angka rataan yang diikuti huruf yang sama pada kolom yang sama tidak berbeda nyata pada taraf $5 \%$ dalam uji T.

Tabel 2. Rata-rata jumlah individu wereng batang cokelat sebanyak empat generasi pada dua varietas padi

\begin{tabular}{lcccc}
\hline \multirow{2}{*}{ Varietas } & \multicolumn{4}{c}{ Generasi ke- } \\
\cline { 2 - 5 } & 0 & 1 & 2 & 3 \\
\hline Ciherang & $1.348,4 \pm 118,7 \mathrm{a}$ & $1.698,5 \pm 47,29 \mathrm{a}$ & $1.717,5 \pm 34,61 \mathrm{a}$ & $1.727,9 \pm 26,75 \mathrm{a}$ \\
IPB 3S & $1.330,4 \pm 115,3 \mathrm{a}$ & $1.667,1 \pm 65,07 \mathrm{a}$ & $1.609 .3 \pm 242,48 \mathrm{a}$ & $1.679 .9 \pm 117,0 \mathrm{a}$
\end{tabular}

Angka-angka rataan yang diikuti huruf yang sama pada kolom yang sama tidak berbeda nyata pada taraf $5 \%$ dalam uji T.

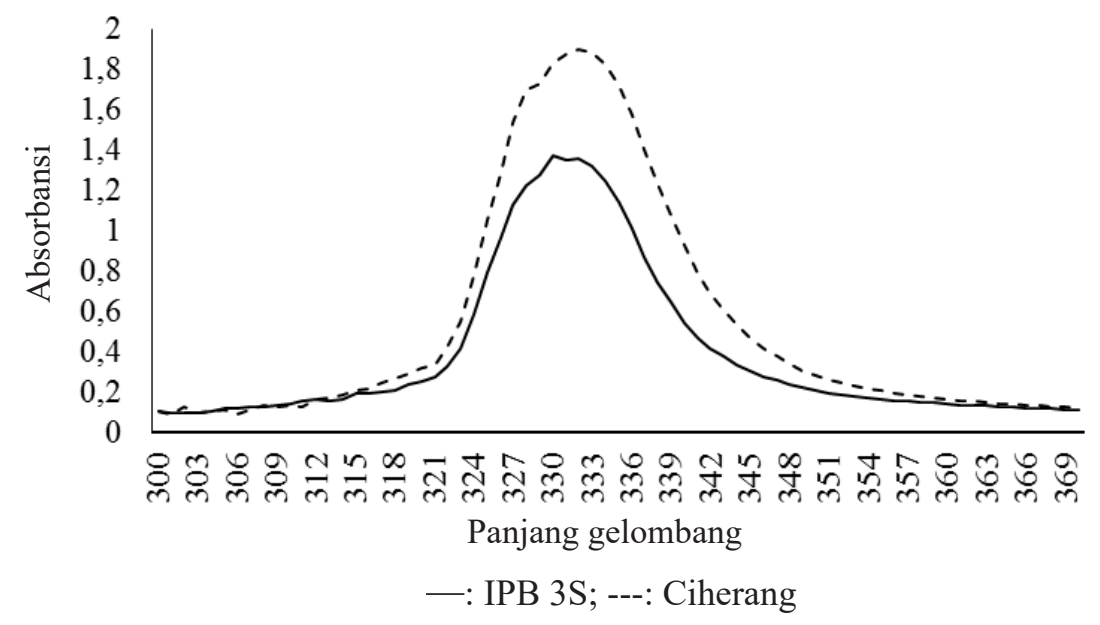

Gambar 2. Nilai absorbansi embun madu wereng batang cokelat pada dua varietas padi. 
keperidian pada dua varietas padi mencapai 411,60 telur/betina pada varietas Ciherang dan 404,10 telur/betina pada varietas IPB 3S.

Perilaku oviposisi dipengaruhi oleh laju kematangan ovari, yang pada varietas rentan WBC lebih survive dibandingkan pada varietas tahan dan varietas tahan dapat menyebabkan WBC gagal dalam memproduksi telur. Rahmini et al. (2012) menyatakan bahwa Inpari 13 yang merupakan varietas tahan memiliki mekanisme antisenosis yang berakibat terjadinya penurunan aktivitas makan pada WBC sehingga jumlah asupan nutrisi yang diperoleh imago WBC selanjutnya berkurang dan terjadi penurunan produksi telur.

Hasil nisbah kelamin, menunjukkan bahwa persentase betina lebih tinggi daripada jantan, dan hal ini berlaku pada kedua varietas. Sementara itu, jumlah betina pada varietas Ciherang lebih banyak dibanding pada varietas IPB 3S, sedangkan jumlah jantan pada varietas IPB $3 \mathrm{~S}$ lebih banyak dibanding varietas Ciherang. Hal ini berarti bahwa potensi perkembangan WBC pada varietas Ciherang lebih cepat dibandingkan pada varietas IPB 3S. Ketersediaan pakan dan jumlah populasi yang rendah sebagai pemicu munculnya jumlah betina, sedangkan kepadatan populasi yang tinggi dan ketersediaan pakan yang rendah akan memicu munculnya jumlah jantan dibandingkan betina. Selain kelimpahan populasi, fekunditas juga berpengaruh terhadap nisbah kelamin WBC pada tanaman padi. Fekunditas merupakan jumlah telur yang dihasilkan oleh betina WBC. Kemampuan berkembang biak akan berpengaruh terhadap fekunditas, dimana tingkat kemampuan berkembang biak berpengaruh pada kecepatan berkembang biak juga perbandingan jumlah jantan dan betina.

Menurut Sutan (2008), betina dengan tingkat keperidian tinggi memiliki peran utama dalam peningkatan laju pertumbuhan suatu populasi serangga. Perbandingan jumlah jantan dan betina akan berpengaruh terhadap jumlah generasi populasi berikutnya, ketika jika jumlah betina lebih banyak daripada jantan maka menghasilkan generasi populasi selanjutnya lebih banyak dibandingkan jika jumlah jantan yang lebih banyak daripada betina.

Secara umum peningkatan populasi WBC pada tiap generasi terjadi secara konsisten pada 102 varietas Ciherang, sementara itu peningkatan populasi pada varietas IPB 3S terjadi berfluktuasi. Namun demikian, peningkatan populasi hingga generasi keempat pada kedua varietas tidak menunjukkan perbedaan nyata pada taraf 5\%. Hal ini diduga karena faktor varietas itu sendiri baik varietas Ciherang maupun varietas IPB 3S, yang berkaitan dengan kebutuhan nutrisi WBC yang terpenuhi dari kedua varietas. Kebutuhan hidup serangga yang terpenuhi dengan kualitas makanan yang baik menyebabkan semakin sempurnanya perkembangan dan pertumbuhan WBC itu sendiri (Zen et al. 1994). Dyck et al. (1979) menyatakan bahwa fase pertumbuhan dan jenis varietas tanaman padi dapat berpengaruh terhadap tinggi rendahnya populasi yang dihasilkan WBC.

Peningkatan jumlah populasi yang terjadi pada dua varietas padi diduga erat hubungannya dengan jumlah telur yang dihasilkan serta banyaknya jumlah betina WBC yang terbentuk. Selain itu, sifat hama WBC yang memiliki kecepatan berkembang biak dan kemampuan menggunakan sumber makanan dengan baik. Hasil penelitian Baehaki \& Widiarta (2009) di Sukamandi menunjukkan bahwa satu pasang WBC pada generasi pertama dapat menghasilkan wereng dewasa 174,5 individu dan pada generasi kedua mencapai 3.700 individu. Cepatnya perkembangan populasi WBC disebabkan oleh tingginya fekunditas yang mencapai 805-908 telur/betina pada generasi ketiga. Hal ini sesuai dengan hasil penelitian yang diperoleh bahwa varietas Ciherang di setiap generasinya terus mengalami peningkatan populasi WBC.

Kemampuan makan WBC diketahui berdasarkan banyaknya embun madu yang dikeluarkan. Semakin banyak WBC menghisap cairan floem pada tanaman padi maka akan semakin banyak embun madu yang dikeluarkan, yang menunjukkan bahwa ketahanan varietas tersebut semakin rendah. Sebaliknya, semakin sedikit WBC menghisap cairan floem pada tanaman padi maka semakin sedikit jumlah embun madu yang dikeluarkan, artinya bahwa varietas tersebut tahan terhadap WBC. Banyaknya embun madu yang dikeluarkan berdasarkan hasil pengukuran secara kualitatif menghasilkan nilai absorbansi yang tinggi, artinya larutan tersebut lebih pekat dalam hal ini kandungan embun madu lebih banyak. Kemampuan makan WBC lebih 
tinggi pada varietas rentan dibandingkan dengan varietas tahan. Seo et al. (2010) menyatakan bahwa WBC mendapatkan kesulitan dalam menghisap cairan floem pada varietas tahan. Ketahanan varietas terhadap hama WBC berkaitan dengan komposisi senyawa pada floem, senyawa kimia pada permukaan tanaman, dan juga respons induksi terhadap serangan WBC (Horgan 2009). Asam amino dan sukrosa merupakan stimulan makan WBC pada tanaman padi (Chen 2009).

\section{KESIMPULAN}

Varietas IPB 3S memiliki ketahanan yang lebih baik terhadap WBC dibandingkan dengan varietas Ciherang. Walaupun tidak ada perbedaan nyata pada keperidian dan peningkatan populasi WBC pada kedua varietas padi, kemampuan makan WBC pada varietas Ciherang cenderung lebih tinggi dari kemampuan makan pada varietas IPB 3S.

\section{DAFTAR PUSTAKA}

Baehaki SE, Widiarta IN. 2009. Hama wereng dan cara pengendaliannya pada tanaman padi. Di dalam: Daradjat AA, Setyono A, Makarim AK, Hasanuddin A (Eds.), Padi Inovasi Teknologi Produksi. hlm. 347-348. Jakarta: LIPI Press.

BPS [Badan Pusat Statistik]. 2016. Produksi Padi Menurut Provinsi (Ton). Tersedia pada: https:// www.bps.go.id/linkTableDinamis/view/id/865. [diakses 25 September 2018].

Chen Y. 2009. Variation in planthopper-rice interactions: possible interactions among three species?. Di dalam: Heong KL, Hardy B (Eds.), Planthoppers: New Threats to the Sustainability of Intensive Rice Production Systems in Asia. hlm. 315-326. Filipina: International Rice Research Institute.

Dyck VA, Misra BC, Alum S, Chen CN, Hsieh CY, Rejesus RS. 1979. Ecology of the brown planthopper in tropics. Di dalam: Brown Planthoppers: Threat to Rice Production in Asia. hlm. 61-98. Los Banos: International Rice Research Institute.

Ellers J, Jervis M. 2003. Body size and the timing of egg production in parasitoid wasps. Oikos
102:164-172. doi: https://doi.org/10.1034/ j.1600-0706.2003.12285.x.

Harini SA, Kumar SS, Balaravi P, Sharma R, Dass AM, Shenoy V. 2013. Evaluation of rice genotypes for brown planthopper (BPH) resistance using molecular markers and phenotypic methods. African Journal of Biotechnology 12:2515-2525.

Horgan FG. 2009. Mechanisms of resistance: a major gap in understanding planthopper-rice interactions. Di dalam: Heong KL, Hardy B (Eds.), Planthoppers: New Threats to the Sustainability of Intensive Rice Production Systems in Asia. hlm. 281-302. Los Banos: International Rice Research Institute.

Nurbaeti B, Diratmaja IGPA, Putra S. 2010. Hama Wereng Cokelat (Nilaparvata lugens (Stål)) dan Pengendaliannya. Lembang: Balai Pengkajian Teknologi Pertanian Jawa Barat.

Priyatno D. 2013. Analisis Korelasi, Regresi, dan Multivariate dengan SPSS. Yogyakarta: Gava Media.

Rahmini, Hidayat P, Ratna ES, Winasa IW, Manuwoto S. 2012. Respon biologi wereng batang cokelat terhadap biokimia tanaman padi. Penelitian Pertanian Tanaman Pangan 31:117-123.

Sari N, Syahrawati M, Arneti, Resti Z, Martinius, Rahma H, Sulyanti E, Syahdia E. 2019. Aplikasi insektisida berbahan aktif buprofezin terhadap wereng batang cokelat di keltan rambutan dan keltan sakato kota padang. Hirilisasi IPTEKS 2:272-280.

Seo BY, Jung JK, Choi BR, Park HM, Lee SW, Lee BH. 2010. Survival rate and stylet penetration behavior of current Korean populations of the brown planthopper, Nilaparvata lugens, on resistant rice varieties. Journal of AsiaPasific Entomology 13:1-7. doi: https://doi. org/10.1016/j.aspen.2009.09.001.

Sutan Z. 2008. Interaksi Populasi Wereng Batang Cokelat Nilaparvata lugens (Stål) (Hemiptera: Delphacidae) dengan Kepik Predator Cyrtorhinus lividipennis (Hemiptera: Miridae) pada Padi Ciherang. Skripsi. Bogor: Institut Pertanian Bogor.

Zen, Khairul, Manti I, Nasrun D, Taufik. 1994. Perkembangan populasi wereng cokelat koloni Sumatera Barat pada beberapa varietas unggul padi sawah. Di dalam: Risalah Seminar Balai Penelitian Tanaman Pangan Sukarami Volume IV. hlm. 29-36. Sukarami: Balai Penelitian Tanaman Pangan Sukarami. 